\title{
Rapid serological test for diagnosis of chlamydial ocular infections
}

\author{
S. DAROUGAR, J. D. TREHARNE, D. MINASSIAN, H. EL-SHEIKH, \\ R. J. DINES, AND B. R. JONES \\ From the Virus Laboratory and WHO Centre for Reference and Research on Trachoma and other \\ Chlamydial Infections, Department of Clinical Ophthalmology, Institute of Ophthalmology, London, and \\ the External Eye Diseases Clinic, Moorfields Eye Hospital, London
}

SUMMARY A rapid serodiagnostic test for the diagnosis of paratrachoma (TRIC ophtha!mia neonatorum, inclusion conjunctivitis, TRIC punctate keratoconjunctivitis, and trachoma of sexually transmitted origin) has been developed. The technique is based on using a modified micro-immunofluorescence test for detecting antichlamydial IgG and IgM in the blood and IgG and $\operatorname{IgA}$ in tears. The blood samples are collected on cellulose sponges after a finger prick, and tears are collected by introducing small sponges into the lower conjunctival fornix of the eye. The blood and tear samples collected in this way could be sent to the diagnostic laboratory by post without special arrangements for cold storage.

In general the presence of antichlamydial IgG at a level of $\geqslant 1 / 32$ or $\operatorname{IgM}$ at a level of $\geqslant 1 / 8$ in blood and antichlamydial IgG or $\operatorname{IgA}$ at a level of $\geqslant 1 / 8$ in tears was closely associated with ocular paratrachoma. The combined results of the micro-IF test of blood and tears has yielded the highest rate of positivity $(90 \%)$. In patients with acute untreated paratrachoma the sensitivity of this test was similar to that of irradiated McCoy cells. In patients with a milder infection receiving antibiotics the sensitivity of the serodiagnostic test was superior to that of the cultural test. The high sensitivity and specificity of this rapid, simple and inexpensive serodiagnostic test for the diagnosis of chlamydial ocular infections, coupled with simple and practical methods of collection and transport of blood and tear specimens, offer advantages over cultural tests for routine diagnosis and study of chlamydial ocular infections.

Infection by Chlamydia trachomatis, usually serotypes $\mathrm{A}-\mathrm{C}$, is responsible for hyperendemic trachoma of eye-to-eye transmission and still constitutes a major public health problem in certain developing countries. In industrially developed countries infection of the eye or genital tract by $C$.trachomatis is generally spread by sexual transmission from a genital reservoir of infection, with occasional transfer to the eye. These eye infections present as TRIC agent ophthalmia neonatorum, inclusion conjunctivitis, TRIC agent punctate keratoconjunctivitis, or as trachoma of genital transmission, and are usually caused by serotypes D-K. The incidence of this ocular paratrachoma (Jones, 1975) is likely to increase because of the apparent increase of chlamydial urethritis, cervicitis, proctitis, and salpingitis presenting as so-called 'non-specific'

Address for reprints: Dr S. Darougar, Institute of Ophthalmology, Judd Street, London WCIH 9QS urethritis, cervicitis, etc. (Catterall, 1974; Dunlop, 1974; Juhlin, 1974; Wiesner and Holmes, 1974). Accurate and rapid diagnosis of these infections and the assessment of the efficacy of treatment depend on the availability of sensitive laboratory tests.

The technique of culture in irradiated McCoy cells is the most sensitive test for the detection and isolation of $C$. trachomatis (Darougar et al., 1971; Darougar et al., 1977b). However, it is expensive and requires an established laboratory with adequate facilities and experienced staff.

The presence of antichlamydial antibodies in blood and tears is closely related to inflammatory changes and to the presence of $C$. trachomatis in the eye of patients with ocular chlamydial infections (Dwyer et al., 1972; Treharne et al., 1977b). The micro-immunofluorescence (micro-IF) test (Wang and Grayston, 1970, 1974) is sensitive for the detection of type-specific antichlamydial antibodies 
(Dwyer et al., 1972; Treharne et al., 1977a; Wang and Grayston, 1974). Modification of this technique has resulted in the development of a simplified micro-IF test using pooled antigens instead of individual TRIC serotypes that makes it practicable to use this test for routine diagnosis and for epidemiological studies (Treharne et al., 1977a).

This paper reports the results of testing sera and tears of patients with chlamydial, viral, bacterial, or allergic conjunctivitis in London using the modified micro-IF test, measuring type-specific antichlamydial antibody of various immunoglobulin classes. It also compares the sensitivity of this serological test for the diagnosis of paratrachoma with that of isolation of $C$. trachomatis in irradiated McCoy cells.

\section{Subjects and methods}

Patients included in this study were attending the External Eye Diseases Clinic, Moorfields Eye Hospital, London.

CLINICAL EXAMINATION

Eyes were examined with a Haag-Streit slit lamp. The signs observed graded from 0 to 3 following the method described elsewhere (Darougar et al., 1977a; Dawson et al., 1975).

\section{CELL CULTURE}

Conjunctival swabbings were collected from the whole conjunctiva (upper tarsus, upper fornix and lower lid) of both eyes using 1 swab for each eye (Darougar and Jones, 1971). The methods of culture in irradiated McCoy cells and the identification of inclusions are described previously (Darougar et al., 1971).

\section{BLOOD}

Blood was taken by finger prick. A dry cellulose sponge ( $\mathrm{J}$. Weiss \& Son Ltd) measuring $5 \times 3 \times 1 \mathrm{~mm}$ was used for collection (Fig. $1 a, b$ ). When saturated, the sponge absorbed approximately $0.1 \mathrm{ml}$ of blood that is, equivalent to $0.05 \mathrm{ml}$ of serum. The, saturated sponge was placed in a tightly-stoppered dry plastic capsule and kept at $+4^{\circ} \mathrm{C}$ until transferred to the laboratory, where the sponges were stored at $-70^{\circ} \mathrm{C}$ until tested.

\section{TEARS}

Secretions were collected from the lower conjunctival sac using 1 dry cellulose sponge (Spontex Ltd) measuring $5 \times 2 \times 1 \mathrm{~mm}$ for each eye (Fig. $2 a, b$ ). When saturated, this sponge absorbed approximately $0.05 \mathrm{ml}$ of fluid. The sponges collected from the right and left eye were placed in a tightly-stoppered
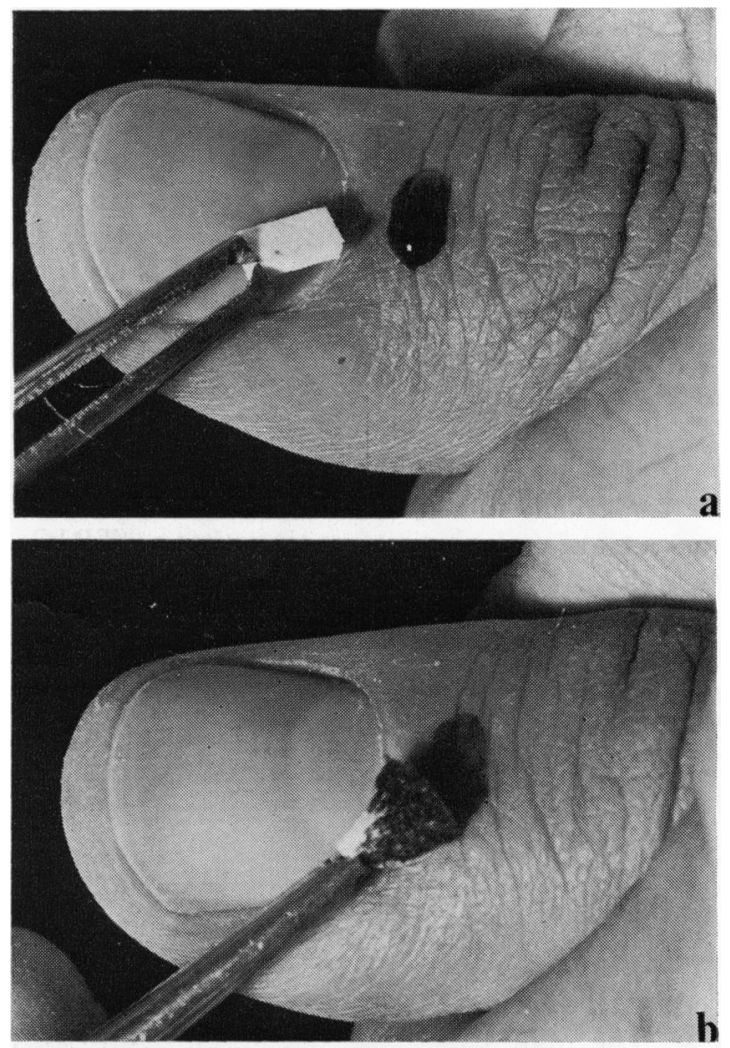

Fig. 1 Method of collection of blood by cellulose sponge following finger prick. (a) Dry sponge. (b) Sponge soaking with blood (full saturation of sponge is required)

dry plastic capsule and stored at $+4 \mathrm{C}$ until transferred to the laboratory, where they were stored in a refrigerator at $-70^{\circ} \mathrm{C}$.

MICRO-IF TEST

Using the modified micro-IF test (Treharne et al., 1977a) antichlamydial IgG levels in blood were titrated in screening dilutions of $1 / 16,1 / 32,1 / 64$, and 1/256. Levels of antichlamydial IgM antibodies in blood were titrated at screening dilutions of $1 / 8$, $1 / 32$, and $1 / 128$, as were antichlamydial $\mathrm{IgG}$ and IgA levels in tears. Goat antihuman IgG, IgM, and IgA fluorescein-labelled conjugates (Hyland Division Travenol Laboratories Inc) at a dilution of $1 / 5$ were used. The other technical procedures for the micro-IF test have been described elsewhere (Dwyer et al., 1972; Treharne et al., 1977a).

\section{Results}

The results of detecting type-specific antichlamydia! antibodies of various immunoglobulin classes in 

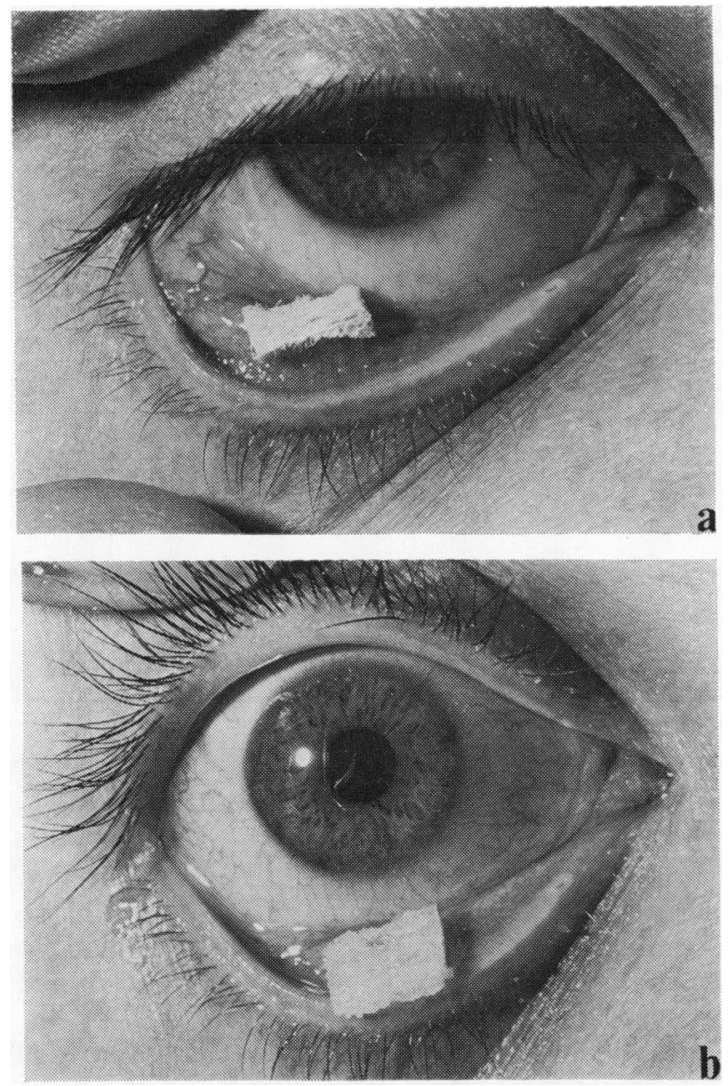

Fig. 2 Method of collection of tears by cellulose sponge. (a) Position of dry sponge in lower conjunctival fornix. (b) Sponge soaked with tears

blood and tears of 282 patients with various ocular infections are shown in Table 1.
In blood $\mathrm{IgG}$ at a range of $1 / 16$ to $1 / 256$ was detected in 82 patients. In 28 of these the IgG level was $1 / 16 ; 14(50 \%)$ of these were patients with clinical ocular paratrachoma (Table 1). In the remaining 54 patients the IgG level was $>1 / 32$. Of these, $44(81 \%)$ were patients with clinical ocular paratrachoma (Table 1). In blood $\operatorname{IgM}$ at a range of $1 / 8$ to $1 / 32$ was found in 24 patients. Twenty-one $(88 \%)$ of these were patients with ocular paratrachoma (Table 1). Antichlamydial antibodies were not detected in blood of 4 out of 52 patients with paratrachoma.

In tears IgG in a range of $1 / 8$ to $1 / 128$ was found in 45 patients (Table 1). Of these, $43(96 \%)$ were patients with clinical ocular paratrachoma. IgA at a range of $1 / 8$ to $1 / 32$ was detected in 20 patients, all of whom were suffering from paratrachoma. Antichlamydial antibodies were not detected in tears of 18 patients with paratrachoma.

The relationship between paratrachoma and the levels of IgG and IgM in blood and the levels of IgG and IgA in tears is shown in Tables 1 and 2.

In general the presence of antichlamydial IgM in blood or antichlamydial IgG or IgA in tears was clearly associated with ocular paratrachoma (Table 1). However, the combined results of the micro-IF test of blood (IgG at a level of $\geqslant 1 / 32$ and IgM at a level of $\geqslant 1 / 8$ ) and/or tears (IgG and IgA at a level of $\geqslant 1 / 8$ ) has yielded the highest rate of positivity $(90 \%)$ (Table 2). This is similar to the rate of positivity obtained from this group by isolation in irradiated McCoy cell culture (87\%) (Table 2).

No chlamydia was isolated from 21 patients with clinically active paratrachoma who were under treatment with antibiotics. In these patients the micro-IF test on blood and tears were positive in $16(76 \%)$ (Table 2$)$.

Table 1 Levels of antichlamydial antibodies of various immunoglobulin classes detected by the modified micro-IF test in blood and tears of 282 patients with various ocular infections

\begin{tabular}{|c|c|c|c|c|}
\hline \multirow[b]{2}{*}{$\begin{array}{l}\text { Type of } \\
\text { specimen }\end{array}$} & \multirow[b]{2}{*}{$\begin{array}{l}\text { Class and titre of } \\
\text { antibody }\end{array}$} & \multirow[b]{2}{*}{$\begin{array}{l}\text { No. of } \\
\text { patients }\end{array}$} & No. $(\%)$ patients & No. $(\%)$ patients \\
\hline & & & Active paratrachoma & Other (viral, bacterial, etc.) \\
\hline \multirow[t]{5}{*}{ Blood } & $\operatorname{IgG}$ at $1 / 16$ & 28 & $14(50 \%)$ & $14(50 \%)$ \\
\hline & IgG at $1 / 32$ & 10 & $8(80 \%)$ & $2(20 \%)$ \\
\hline & IgG at $1 / 64$ or higher & 44 & $36(82 \%)$ & $8(18 \%)$ \\
\hline & IgM at $1 / 8$ or higher & 24 & $21(88 \%)$ & $3(12 \%)$ \\
\hline & No antibodies & 200 & $4(2 \%)$ & $196(98 \%)$ \\
\hline \multirow[t]{3}{*}{ Tears } & IgG at $1 / 8$ or higher & 45 & $43(96 \%)$ & $2(4 \%)$ \\
\hline & IgA at $1 / 8$ or higher & 20 & $20(100 \%)$ & $\mathbf{0}$ \\
\hline & No antibodies & 223 & $18(8 \%)$ & $205(92 \%)$ \\
\hline
\end{tabular}


Table 2 Relationship between levels of antichlamydial antibodies detected by the modified micro-IF test in blood and tears of 282 patients and the diagnosis of their ocular or other infections

\begin{tabular}{|c|c|c|c|c|c|}
\hline & & & Blood & Tears & \\
\hline Diagnosis & $\begin{array}{l}\text { No. of } \\
\text { patients }\end{array}$ & $\begin{array}{l}\text { Positive culture } \\
\text { for chlamydia }\end{array}$ & $\begin{array}{l}\operatorname{Ig} G \text { at } 1 / 32 \text { or higher } \\
\operatorname{Ig} M \text { at } 1 / 8 \text { or higher }\end{array}$ & $\left.\begin{array}{l}\operatorname{Ig} G \\
\operatorname{Ig} A\end{array}\right\}$ at $1 / 8$ or higher & $\begin{array}{l}\text { Blood and } \\
\text { tears }\end{array}$ \\
\hline $\begin{array}{l}\text { Paratrachoma } \\
\text { Active untreated }\end{array}$ & 39 & $34(87 \%)$ & $30(77 \%)$ & $33(85 \%)$ & $35(90 \%)$ \\
\hline Isolation + ve & 34 & 34 & $23(68 \%)$ & $29(85 \%)$ & $31(91 \%)$ \\
\hline Treated, but actively inflamed & 21 & 0 & $14(67 \%)$ & $9(43 \%)$ & $16(76 \%)$ \\
\hline Cured & 8 & 0 & 0 & 0 & 0 \\
\hline Ophthalmia neonatorum & 2 & 1 & 1 & 1 & 1 \\
\hline $\begin{array}{l}\text { Follicular conjunctivitis of } \\
\text { unknown etiology }\end{array}$ & 3 & 0 & 0 & $\mathbf{i}$ & 1 \\
\hline Non-specific genital infection* & 4 & $\mathrm{ND} \dagger$ & 4 & 2 & 4 \\
\hline $\begin{array}{l}\text { Other conjunctivitis (viral, bacterial, } \\
\text { allergic, etc.) }\end{array}$ & 205 & ND & $6(3 \%)$ & $1(0.5 \%)$ & $7(3 \%)$ \\
\hline
\end{tabular}

*Patients attended because of adenovirus or allergic conjunctivitis. +ND - Not done

Four patients attending the clinic because of an adenovirus or allergic conjunctivitis were concomitantly suffering from a non-specific urethritis or cervicitis. The micro-IF test was positive in blood of all 4 patients and in the tears of 2 .

In 205 patients suffering from non-chlamydial conjunctivitis (viral, bacterial, and others) the micro-IF test on blood as well as tears was positive in $7(3 \%)$ (Table 2$)$. No attempt had been made to determine the presence of concomitant chlamydial genital infections in these 7 patients.

In all patients except 2 the antichlamydial antibodies detected were against TRIC serotypes D-K. In these 2 patients the antibodies found were against TRIC serotypes A-C, responsible for hyperendemic trachoma.

\section{Discussion}

The simplified one-passage technique of culture in irradiated McCoy cells provides a rapid and sensitive test for the isolation of chlamydia. With this test chlamydial isolates were obtained from $90 \%$ of cases of TRIC ophthalmia neonatorum and inclusion conjunctivitis in London and up to $82 \%$ of cases of severe hyperendemic trachoma in Tunisia (Darougar t al., 1977b). The technique of culture in irradiated McCoy cells or alternative cultural systems, namely, McCoy cells treated with idoxuridine or cycloheximide (Wentworth and Alexander, 1974; Ripa and Mardh, 1977), HeLa cells treated with DEAEdextran (Kuo et al., 1972) are also complicated methods that require an established laboratory with adequate facilities and experienced staff.
Earlier studies in this laboratory have shown that levels of antichlamydial antibody in separated serum are generally twofold higher than the levels of antibody found in whole blood collected on cellulose sponges. The technique of collection of blood on sponges, however, is far simpler and more rapid than venepuncture.

Recent studies have shown that antichlamydial IgG is present in the sera of over $80 \%$ of patients with ocular chlamydial infections (Treharne et al., 1977b). In patients presenting with ocular paratrachoma the level of antichlamydial antibody found in the sample of blood collected during the acute phase of the infection is generally high, and remains at this level during the course of the disease, because of the concomitant genital chlamydial infection that usually precedes the eye infection. Therefore the diagnostic fourfold rise in the titre of antibody cannot be shown in the convalescent serum of the majority of these patients.

In this study $\operatorname{IgG}$ at a level of $1 / 16$ was present in the blood of 14 patients with no obvious ocular or genital chlamydial infections (Table 1). Studies in our laboratory have shown that IgG in the blood may remain for some months after recovery from chlamydial ocular or genital infection. Hence the presence of IgG antibody at a low level may indicate a previous exposure to these infections.

In the blood antichlamydial IgG at a level of $\geqslant 1 / 32$ correlates well with clinically active paratrachoma. The presence of antichlamydial IgM in the blood and $\operatorname{IgG}$ or $\operatorname{IgA}$ in the tears is highly specific and faithfully reflects activity of ocular chlamydial infection. 
The result of this work indicates that the modified micro-IF test on blood and tears together is a highly sensitive test for the diagnosis of paratrachoma. In patients with acute untreated paratrachoma the sensitivity of this test was similar to that of culture in irradiated McCoy cells. In 21 patients originally isolation-positive, who were inadequately treated with antibiotics and were still showing signs of active inflammatory changes in their eyes, the micro-IF test on blood and tears was positive in $16(76 \%)$, whereas cell culture failed to detect chlamydia.

In addition to the high sensitivity the micro-IF test on blood and tears shows a very high degree of specificity. Of 205 patients who were suffering from a clinically or microbiologically diagnosed adenovirus, herpes virus, bacterial or allergic conjunctivitis, the micro-IF test was positively only in 7 . Although these 7 patients were not investigated further, the possibility of a mild or atypical form of TRIC ocular infection or a concomitant or previous mild or asymptomatic genital chlamydial infection in them cannot be ruled out.

In the present group 4 patients with adenovirus or allergic conjunctivitis had a mild urethritis or cervicitis. The micro-IF test on blood was positive in all these cases and on tears in 2. Although this number of cases is too small to draw any conclusions, the result indicates that this test may be useful for the detection of chlamydial genital infections.

The modified micro-IF test has provided a rapid, simple, and inexpensive technique for the detection of immunoglobulin classes of antichlamydial typespecific antibody in the blood and tears. In this study 4 pooled antigens and a normal yolk-sac as control have been used. The pooled antigens are TRIC serotypes A-C (hyperendemic trachoma), TRIC serotypes D-K except J (paratrachoma), LGV 1-3 (lymphogranuloma venereum), and 4 representative isolates of $C$. psittaci. For routine purposes in selected communities the test can be further simplified by using only $\mathrm{A}-\mathrm{C}$ or $\mathrm{D}-\mathrm{K}$ pooled antigens and excluding the LGV and $C$. psittaci pooled antigens. This much simplified micro-IF test can be successfully used for the diagnosis of chlamydial ocular infections of sexually transmitted origin (pooled $\mathrm{D}-\mathrm{K}$ antigens) or for the diagnosis of hyperendemic trachoma of eye-to-eye transmission (pooled A-C antigens).

The egg-grown antigen used in this study (Dwyer et al., 1972; Treharne et al., 1977a) has several advantages over cell-grown antigens (Richmond and Caul, 1975). Inoculating fertile hens' eggs with chlamydia and harvesting the infected yolk-sac is a simple: procedure. One heavily infected egg provides sufficient antigen for 2500 or more tests. A freezedried antigen may be stored for several months at $4 \mathrm{C}$ or at room temperature without a marked loss of antigenicity. With the possibility of mass production and subsequent lyophilisation the antigen could be prepared by a national or international centre and distributed to other laboratories for routine diagnosis or study of chlamydial ocular infections.

In addition to the antigen the micro-IF test requires a fluorescent microscope and commercially available antihuman IgG, IgM, and IgA fluorescein-labelled conjugates. The staining technique and the screening of stained slides is simple and rapid, taking up to 2 hours. A technician with 2 to 3 weeks' training can test over 100 specimens a day.

Collection of blood and tear samples using dry sponges is simple, rapid, and does not require highly trained staff. We have shown that tear and blood samples collected in this way could be stored at room temperature or at $4 \mathrm{C}$ for 1 week without a marked decrease in the level of antibody. Therefore specimens could be sent by post without special arrangement for cold storage.

The high sensitivity and specificity of this rapid, simple, and inexpensive serodiagnostic test, coupled with simple and practical method of collection and transport of blood and tears specimens, offer advantages over the cultural tests for routine diagnosis of ocular chlamydial infections.

Work is in hand to apply this rapid serodiagnostic test for the diagnosis of chlamydial genital infections and for hyperendemic trachoma.

The authors are grateful to colleagues at Moorfields Eye Hospital for referring their patients.

This work is financially supported by grants from the Department of Health and Social Security and an anonymous donor.

\section{References}

Catterall, R. D. (1974). The situation of gonococcal and nongonococcal infections in the United Kingdom. In Genital Infections and their Complications, p. 5. Edited by D. Danielsson, L. Juhlin, and P.-A. Mardh. Almqvist \& Wiksell International: Stockholm.

Darougar, S., and Jones, B. R. (1971). Conjunctival swabbing for the isolation of TRIC agent (Chlamydia). British Journal of Ophthalmology, 55, 585-590.

Darougar, S., Kinnison, J. R., and Jones, B. R. (1971). Simplified irradiated McCoy cell culture for isolation of Chlamydia. In Trachoma and Related Disorders Caused by. Chlamydial Agents, p. 63. Edited by R. L. Nichols. Excerpta Medica: Amsterdam.

Darougar, S., Viswalingam, N., Treharne, J. D., Kinnison, J. R., and Jones, B. R. (1977a). Treatment of TRIC 
infection of the eye with rifampicin or chloramphenicol. British Journal of Ophthalmology, 61, 255-259.

Darougar, S., Woodland, R. M., Forsey, T., Cubitt, S., Allami, J., and Jones, B. R. (1977b). Isolation of Chlamydia from ocular infections. In Nongonococcal Urethritis and Related Infections, p. 295. American Society of Microbiology.

Dawson, C. R., Jones, B. R., and Darougar, S. (1975). Blinding and non-blinding trachoma: assessment of intensity of upper tarsal inflammatory disease and disabling lesions. Bulletin of the World Health Organisation, 52 279-282.

Dunlop, E. M. C. (1974). Non-specific genital infection: relation to Chlamydia. New tests for chlamydial infection and their application to lymphogranuloma venereum. In Recent Advances in Sexually Transmitted Diseases, p. 267. Edited by R. S. Morton and J. R. Harris. ChurchillLivingstone: Edinburgh and London.

Dwyer, R. St. C., Treharne, J. D., Jones, B. R., and Herring, J. (1972). Results of micro-immunofluorescence tests for detection of type-specific antibody in certain chlamydial infections. British Journal of Venereal Diseases, 48, 452-459.

Jones, B. R. (1975). The prevention of blindness from trachoma. Transactions of the Ophthalmological Societies of the United Kingdom, 95, 16-33.

Juhlin, L. (1974). The situation of gonococcal and nongonococcal infections in Sweden and other Scandinavian countries. In Genital Infections and their Complications, p. 25. Edited by D. Danielsson, L. Juhlin, and P.-A. Mardh. Almqvist \& Wiksell International: Stockholm.

Kuo, C. C., Wang, S. P., Wentworth, B. B., and Grayston, J. T. (1972). Primary isolation of TRIC organisms in HeLa 229 cells treated with DEAE-dextran. Journal of
Infectious Diseases, 125, 665-668.

Richmond, S. J., and Caul, E. O. (1975). Fluorescent antibody studies in chlamydial infections. Journal of Clinical Microbiology, 1, 345-352.

Ripa, K. T., and Mardh, P.-A. (1977). A new simplified culture technique for Chlamydia trachomatis. In Nongonococcal Urethritis and Related Infections, p. 323. American Society of Microbiology.

Treharne, J. D., Darougar, S., and Jones, B. R. (1977a). Modification of the micro-immunofluorescence test to provide a routine serodiagnostic test for chlamydial infection. Journal of Clinical Pathology, 30, 510-517.

Treharne, J. D., Dines, R. J., and Darougar, S. (1977b). Serological responses to chlamydial ocular and genital infections in the UK and Middle East. In Nongonoccal Urethritis and Related Infections, p. 249. American Society of Microbiology.

Wang, S. P., and Grayston, J. T. (1970). Immunologic relationship between genital TRIC, lymphogranuloma venereum and related organisms in a new microtiter indirect immunofluorescence test. American Journal of Ophthalmology, 70, 367-374.

Wang, S. P., and Grayston, J. T. (1974). Human serology in Chlamydia trachomatis infection with micro-immunofluorescence. Journal of Infectious Diseases, 130, 388-397.

Wentworth, B. B., and Alexander, E. R. (1974). The use of IUDR-treated cells for the isolation of Chlamydia trachomatis. Journal of Applied Microbiology, 27, 912-916.

Wiesner, P. J., and Holmes, K. K. (1974). Current view of the epidemiology of sexually transmitted diseases in the United States. In Genital Infections and their Complications, p. 15. Edited by D. Danielsson, L. Juhlin, and P.-A. Mardh. Almqvist \& Wiksell International: Stockholm. 